\title{
COMPARATIVE TASTE ANALYSIS OF SMOKED HILSA (Tenualosa ilisha) TREATED WITH DIFFERENT SPICES
}

\author{
Soma Saha*, Rashnat Moushomi and Balai Chandra Bhowmik \\ Department of Fisheries and Marine Science, Noakhali Science and Technology \\ University, Sonapur, Noakhali 3814, Bangladesh \\ *Corresponding author: Soma Saha, E-mail: shahasoma.nstu@gmail.com
}

\begin{tabular}{|c|c|}
\hline ARTICLE INFO & ABSTRACT \\
\hline $\begin{array}{l}\text { Received } \\
22.07 .2015 \\
\text { Accepted } \\
25.08 .2015 \\
\text { Online } \\
04.09 .2015 \\
\text { Key words } \\
\text { Smoking } \\
\text { Tenualosa ilisha } \\
\text { Taste } \\
\text { Treatments } \\
\text { Spices } \\
\text { Brine solution }\end{array}$ & $\begin{array}{l}\text { The present study was conducted to examine the taste of smoked hilsa (Tenualosa ilisha) } \\
\text { treated with different spices (salt, garlic, onion, ginger and green chilly). Fresh hilsa fish were } \\
\text { collected from different markets of Noakhali. The study was conducted for a period of five } \\
\text { months from April to August } 2013 \text {. Hilsa were smoked with different combinations of salt, } \\
\text { garlic, onion, ginger and green chilli. At first the fish were grouped into four segments. One } \\
\text { segment composed of salt, garlic }(50 \mathrm{~g} / \mathrm{kg}) \text {, onion }(250 \mathrm{~g} / \mathrm{kg}) \text {, ginger }(50 \mathrm{~g} / \mathrm{kg}) \text { and green chilli } \\
(50 \mathrm{~g} / \mathrm{kg}) \text { was treated as treatment } 1\left(\mathrm{~T}_{1}\right) \text {. Treatment } 2\left(\mathrm{~T}_{2}\right) \text { composed of salt, onion }(250 \mathrm{~g} / \mathrm{kg}) \text {, } \\
\text { garlic }(50 \mathrm{~g} / \mathrm{kg}) \text { and ginger }(65 \mathrm{~g} / \mathrm{kg}) \text {. Other part composed of salt, ginger }(120 \mathrm{~g} / \mathrm{kg}) \text { and garlic } \\
(90 \mathrm{~g} / \mathrm{kg}) \text { treated as Treatment } 3\left(\mathrm{~T}_{3}\right) \text {. The treatment } 4\left(\mathrm{~T}_{4}\right) \text { consist of salt, garlic }(90 \mathrm{~g} / \mathrm{kg}) \text { and } \\
\text { onion (350g/kg). Brine concentration for each treatment was about } 70 \mathrm{ppt} \text { that produce good } \\
\text { test and flavor. } 30 \text { panelists check four treatments. Among the four treatments } \mathrm{T}_{1} \text { showed } \\
\text { better results. About } 80 \% \text { panelists replied that treatment } 1\left(\mathrm{~T}_{1}\right) \text { smoked hilsa was excellent } \\
\text { and } 20 \% \text { said that it was very good. Peppery taste was found highest as } 65 \% \text { in the } T_{1} \text {. Salty } \\
\text { taste was strong about } 12 \% \text { in } T_{2} \text { and neutral is about } 85 \% \text { in } T_{1} . \text { Odour in } T_{4} \text { was found } \\
\text { highest ( } 52 \%) \text { among the four treatment due to its low spicy \& smoky flavor. Color and } \\
\text { external appearances of smoked hilsa was overall good. Texture of } T_{1} \text {, } T_{2} \text {, } T_{3} \text { were soft and } \\
\text { oily but in } T_{4} \text { there were found slightly rubbery skin. Smoking is a popular method of fish } \\
\text { preservation in many countries of the world. Smoked hilsa may be a commercialized food } \\
\text { item if fish smoked with different spices. It can be said that } T_{1} \text { was the best among the four } \\
\text { treatments. So smoking hilsa fish with salt, garlic, onion, ginger and green chilli may be the } \\
\text { potential food item in national and international market due to its spicy, good taste and flavor. }\end{array}$ \\
\hline
\end{tabular}

To cite this article: S Saha, R Moushomi and BC Bhowmik, 2015. Comparative taste analysis of smoked hilsa (Tenualosa ilisha) treated with different spices. Res. Agric. Livest. Fish. 2 (2): 307-312.

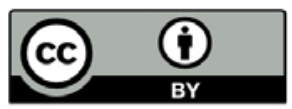

This is an open access article licensed under the terms of the Creative Commons Attribution 4.0 International License

www.agroaid-bd.org/ralf, E-mail: editor.ralf@gmail.com 


\section{INTRODUCTION}

Fish is one of the famous and popular food items to the people of Bangladesh. Fish is the dominant kind of protein source in Bengali cuisine. Fish contains on an average 15-20\% protein and hence it is the single highest human protein source (animal source) especially in developing countries all over the world (Nowsad, 2011). The climatic condition of the country (moderate temperature, heavy rainfall during monsoon seasons) is also suitable to support the culture of fish. Fisheries, the high growing sector, contributed about $2.46 \%$ of the total export earning, $4.39 \%$ to GDP and $22.76 \%$ to agricultural sector (DoF, 2013). Hilsa lives in the sea for most of its life, but migrates up to $1,200 \mathrm{~km}$ inland through rivers in the Indian sub-continent for spawning (Hossain, 2012). The unique taste of hilsa has been attributed due to the presence of many mono and poly unsaturated fatty acids, viz., oleic, lenoleic, lenoleneic, arachidonic, eicosapentaenoeic and docosahexaenoeic acids (Nowsad et al, 2012). Hilsa is tastier just before the spawning than post-spawning or maturing stages. Female hilsa grows faster, becomes larger and tastier than the male of same age group. Riverine hilsa, especially those from the river Padma, are tastier than marine ones. After catch, fish quality degrades due to three reasons, i.e.; autolysis, oxidation and bacterial decomposition. So to avoid the spoilage of fish preservation is must. Fish can be preserved through various methods such as chilling and icing of fish, freezing of fish, sun drying of fish and processed by smoking, salting, fermentation, canning of fish etc (Nowsad, 2007).

Smoking is a method of fish preservation affected by a combination of drying and deposition of naturally produced chemicals resulting from the thermal breakdown of wood (Rawson, 1966). In smoking fire producing smoke can generate heat and dry the fish and thus reduce the water activity. Hot smoking cooks the flesh and thus destroys enzymes and kills the bacteria. Cold smoking means curing fish by smoking at an air temperature not higher than $33^{\circ} \mathrm{C}$ to avoid cooking the flesh or coagulating the protein; with the one exception of smoked salmon. The smoking process is used for hundreds of years either to preserve and the shelf-life of foods or to give them specific organoleptic characteristics (taste, flavour) (Berhimpton, 1991). Smoked Hilsha (river shad: Tenualosa ilisha) has been a popular product in some coastal districts like Cox's Bazar since ancient time.

In Bangladesh a lot of works were carried on drying (Ahmed et al., 1979; Morshed, 2005), salting and freezing (Rabbane, 2006; Sarmin, 2008) but few scientific works on smoke curing. On the other hand smoke curing method is the method which is not affected by climatic condition as well as the smoke cured product has a special taste and color and flavour that attracts consumer. The purpose of the present research activities was to investigate the effectiveness of smoking with salt, garlic, chilli, onion and ginger treatment to make the fish delicious and ready food item that will contain adequate amount spices. Curing Smoked hilsa fish could become a popular food item both at home and profitable commercial food industry in Bangladesh for their taste, appearance and smoky flavor.

\section{MATERIALS AND METHODS}

The study was carried out to standardize smoking procedure using available and most popular national fish hilsa, and evaluate taste with different spices.

\section{Experimental fish}

In the present study, popular fish species Tenualosa ilisha was used. The methodology applied to this study are illustrated in the diagram (Figure 1).

\section{Experimental design}

The fishes (500 gm each) were grouped into four categories. The first category composed of salt, garlic, onion, ginger and green chilli treated as Treatment $1\left(T_{1}\right)$. Another was Treatment $2\left(T_{2}\right)$ that contains salt, onion, garlic and ginger. The other part contained salt, garlic and ginger was treated as Treatment $3\left(T_{3}\right)$. The treatment $4\left(\mathrm{~T}_{4}\right)$ contain garlic and onion. 
The study was conducted for a period of five months from April to August 2013, in the laboratory of the Department of Fisheries and Marine Science, Noakhali Science and Technology University. The samples were bought from Sonapur market Noakhali.

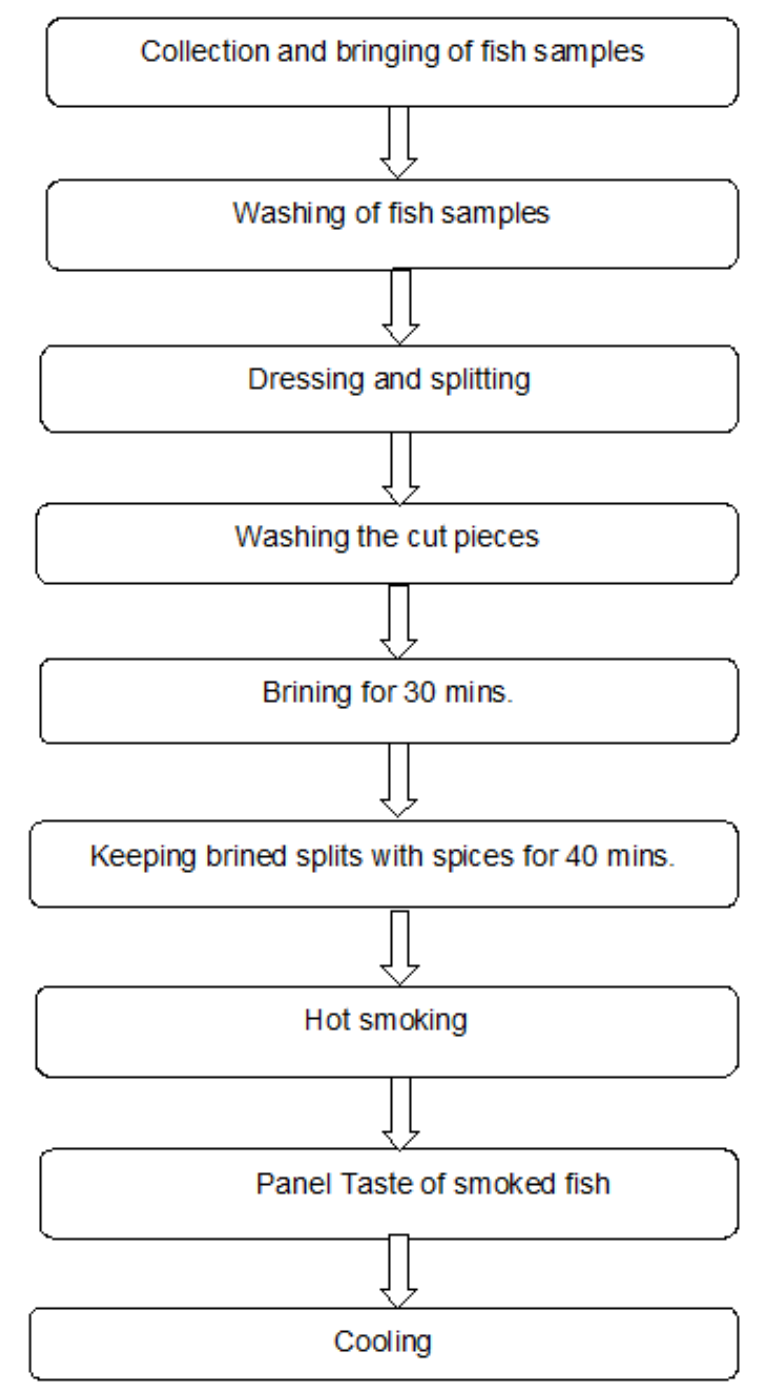

Figure 1. Diagram of the methodology applied in the study

\section{Preparation of the smoking curing of the experiment}

The experimental fishes were quickly carried to the laboratory as early as possible to avoid any spoilage during the period. They were washed properly with clean tap water. Then the fishes were degutted and splitted for smoke curing. Smoke curing process involves five basic steps.

Step 1 (cleaning, dressing, splitting and washing of fish)

The fishes were first washed to remove loose scales and slime, and then remove scales, gutted and beheaded. The belly cavity should be cleaned to remove traces of blood, and any black belly wall lining removed. Then fishes were cut transversely into small pieces (in average $1.7 \mathrm{~cm}$ thick) and then again washed with clean water before bringing them. After that, the fishes were kept for a while to remove the water. Then the fishes were weighted. Then alls the fish pieces are grouped into four different sample. 
Step 2 (Brining)

Hilsa fish for hot smoking are brined to give them flavour. Research shows that, 70ppt concentration of brine that brought good result for the taste of somked hilsa and develops a good flavour. Immersion time was $30 \mathrm{~min}$.

\section{Step 3 (mixing of spices)}

Four different spices differently used in four treatments. Spices give the final product good flavour and taste. The ingredients were selected in respect to the choices of Bangladeshi people. Ingredients were first weighed in dry condition. Then spices were blended properly. Later, we mixed all the ingredients thoroughly. Following mixing, the fish pieces were kept for 40 minutes for well penetration of all ingredients to the inner part to achieve the best curative and flavouring effect from spices. Extra spices were drained off by keeping in plastic tray.

Table 1. Name and quantity of ingredients used in the four treatments

\begin{tabular}{ll}
\hline Name of the treatments & Average Quantity of each spice in each treatment \\
\hline Treatment $T_{1}$ & Onion $(250 \mathrm{~g} / \mathrm{kg})+$ garlic $(50 \mathrm{~g} / \mathrm{kg})+$ ginger $(50 \mathrm{~g} / \mathrm{kg})+$ chilly $(50 \mathrm{~g} / \mathrm{kg})$ \\
Treatment $T_{2}$ & Onion $(250 \mathrm{~g} / \mathrm{kg})+$ garlic $(50 \mathrm{~g} / \mathrm{kg})+$ ginger $(65 / \mathrm{kg})$ \\
Treatment $T_{3}$ & Garlic $(90 \mathrm{~g} / \mathrm{kg})+\operatorname{ginger}(120 \mathrm{~g} / \mathrm{kg})$ \\
Treatment $\mathrm{T}_{4}$ & Onion $(350 \mathrm{~g} / \mathrm{kg})+$ garlic $(90 \mathrm{~g} / \mathrm{kg})$ \\
\hline
\end{tabular}

\section{Step 4 (Smoking and drying)}

a. The fish pieces were hanging on the iron hooks and arranged in a kiln so that either the backs or the bellies of the fish face the smoke flow.

b. Fire was built on level ground with non-resinous wood chip with charcoal.

c. The temperature was most of the time about $70-80^{\circ} \mathrm{C}$. The relative measure using hygrometer.

d. Processing time of smoked fish will depend on the species, its size and fat content, and the kind of product required.

\section{Step 5 (Cooling)}

Hot smoked fish must be allowed to cool to at room temperature. Then the smoked hilsa served to panellist.

\section{Taste assessment of smoked products:}

Taste of smoked products was assessed by panel testing where 30 persons were included in panel .of which all of them were university students and teacher. Each of them was provided with eight pieces (two from each species) of smoked product along with a pre-prepared form to be filled up. Four parameters (odour, salty taste, smoky flavor, peppery) were considered each having seven arbitrary ranks. Then, the percentage of the values got from the panelists were calculated and considered as the final value for that parameter.

$$
\begin{aligned}
& 7=\text { Excellent } \\
& 6=\text { Very good }+=\text { Present } \\
& 5=\text { Good } \quad-\quad=\text { Absent } \\
& \text { 4= Average } \quad 0=\text { Neutral } \\
& \text { 3=Poor }
\end{aligned}
$$




\section{RESULT AND DISCUSSION}

\section{Standardization of brine concentration}

The brine concentrations of the 4 treatments $\left(\mathrm{T}_{1} \mathrm{~T}_{2} \mathrm{~T}_{3} \mathrm{~T}_{4}\right)$ are fixed at 70 ppt. Among these treatments, 70 ppt shows appropriate salt concentration in proportion to the body weight of fish. The amount of salt have penetrated into fish flesh is sufficient \& helps to make fish flesh tasty. On the other hand, panel test result show the brine concentration of 80 ppt. \& 90 ppt. is high in proportion to body weight and 50ppt \& 60 ppt show lower salt concentration according to their body weight.

\section{Standardization of brining time}

To standardize the brining time, we had immersed the hilsa pieces for different time phase. The best result that shows the perfect salt concentration in the fish body muscle takes time for about 30 minutes.

\section{Standardization of smoking procedure}

To standardize the brine parameter and smoking time appropriate to hilsa fish, we have done several treatments with only 70 ppt brine concentrations.

\section{Standardization of smoking time}

Different species needs different smoking time. Hilsa is one of the most popular fatty fish and for smoking need more than 2 hour. Smoking time for hilsa is about 3-3.30 hr.

\section{Taste of the smoked fish}

About $80 \%$ panelists said that treatment $\left(T_{1}\right)$ smoked hilsa is excellent and $20 \%$ said that it is very good. In the treatment $T_{1}$ as spices salt, garlic, onion, ginger and green chilli are used. $T_{1}$ shows good result because combination of all spices is used during the experiment in the treatment $T_{1}$ and there is a significant peppery taste is found. $T_{1}$ contain salt, garlic, $(50 \mathrm{~g} / \mathrm{kg})$, onion $(250 \mathrm{~g} / \mathrm{kg})$, ginger $(50 \mathrm{~g} / \mathrm{kg})$ and green chilli $(50 \mathrm{~g} / \mathrm{kg})$. In case of taste $T_{2}, T_{3}, T_{4}$ were not present good result because of fewer amounts of spices and absence of peppery taste.

Hossain et al. (2012) worked on smoked hilsa. Here three treatments are used during smoking. However, from the results of overall acceptability, taste, colour and texture of the products, Treatment 2 contained 10\% salt and 10\% garlic showed best result. Obande et al. (2012) worked on organoleptic assessment on smoked Clarias gariepinus according to seven point of Hedonic scale. He found the taste is $6.90 \pm 0.10$ (Fish smoked with charcoal) and 6.90 \pm 0.16 (Fish smoked with firewood). Konosu (1979) and Konosu and Yamaguchi (1982) reviewed the taste of fish and shellfishes and concluded that the flavor of fish are distributed to extremely great variety of flavor compounds that are variable according to species and biological conditions.

\section{Strong salty taste}

In treatment $\mathrm{T}_{2}$ about $12 \%$ panelist found strong salty taste at 70 ppt because there here amount of spices is lower and in T1 85\% panelist found neutral salty taste because of higher amount of spices.

\section{Odour taste of smoked hilsa}

In treatment $\mathrm{T}_{4}$ odour is highest. Panelist said the present of odour in $\mathrm{T}_{4}$ is $52 \%$ due to low spicy \& smoky flavor. The absence of odour is highest in treatment $T_{1}$ because appropriate salt and spices are capable of removing odd flavor and fragrance.

\section{Strong smoky flavor}

Panelist said that smoky flavor is present all the treatment but highest smoky flavor is present in the treatment $T_{3}$.Here ginger is used highest amount is about $(120 \mathrm{~g} / \mathrm{kg})$. Ginger may responsible for the development of good smoky flavor.

\section{Peppery taste of smoked hilsa}

About $65 \%$ panelist said that the treatment $\mathrm{T}_{1}$ that have strong perppery taste due to the use of chilli and ginger. In treatment $\mathrm{T}_{3}$ about $15 \%$ panelist said that have medium peppery taste due to the use of ginger. But $\mathrm{T}_{2}$ and $\mathrm{T}_{4}$ treatment that are lack of giner and chilli so panelist found peppery taste in slighty . 


\section{Color of smoked hilsa}

In case of color $45 \%$ panelist said treatment $\mathrm{T}_{1}$ is more good than other , because spices makes colorful appearance.

\section{External appearance of smoked hilsa}

External appearance of the smoked hilsa in four treatment is good. In $T_{1}, T_{2}, T_{3}$ and $T_{4}$ about $24 \%$, $37 \% 19 \%$ and $20 \%$ said that the external apperance is good.

\section{Texture of smoked hilsa}

In $T_{1}, T_{2}, T_{3}$ most panelist said that the texture of smoked hilsa is soft and oily but in $T_{4}$. slighty rubbery skin found.

This research revealed that the application of salt, garlic, onion, ginger and green chilli showed the best result compared to the other treatment due to its good colour, taste, appearance and smoky flavor. Problems of this study were, limited time, study up to one spices level, smoking done manually. It would be better if done with automated device.

\section{REFERENCES}

1. Nowsad, 2011. New ice box in fish transportation and trade. In "National Fisheries Week Souvenir2011", Department of Fisheries, Government Bangladesh, Matshaya Bhaban, Dhaka.

2. Department of Fisheries (DoF), 2013. Fishery Statistical Yearbook of Bangladesh 2011-2012. Fisheries Resources Survey System.Department of Fisheries (DoF), Ministry of Fisheries and Livestock, Dhaka, Bangladesh.

3. Hossain M, RK Adhikary, KR Mahbub, M Bagum and MR Islam, 2012. Effects of $10 \%$ concentrations of Salt, Garlic and Coriander on the Quality of Smoked Hilsa Fish (Tenualosa ilisha). American Journal of Food Technology, 7: 501-505.

4. Nowsad, 2012. Nutritional values, consumption and utilization of Hilsa Tenualosa ilisha (Hamilton1822) Proc. Regional Workshop on Hilsa: Potential for Aquaculture. Department of Fisheries Technology, Bangladesh Agricultural University, Mymensingh, Bangladesh Dhaka, Bangladesh.

5. Nowsad AKMA, 2007. Participatory Training of Trainers: A New Approach Applied in the Fish Processing. Bangladesh Fisheries Research Forum, Dhaka, 328p.

6. Rawson GC, 1966. A short Guide to Fish preservation. Rome. U.S Food and Agriculture Organization: 42-58p.

7. Berhimpton S, RA Souness, RH Doriscoll, KA Buckle and RA Edwards, 1991. Salting behavior of yellow tail (Trachurus mccullochi nichols). Journal of Food Poisoining and Preservation, 15: 101-114.

8. Ahmed ATA, G Mustafa and HN Rahman, 1979. Solar drying of silver jew fish, Johnius argentatus (Hourruyn) in polythene tent dryer. Bangladesh Journal of Biological Science, 8: 23-30.

9. Morshed M, 2005. Design and development of a solar tunnel dryer for dehydration of fresh water and marine fish and quality assessment of dried and dehydrated Mola (Amblyharyngodon mola, HamiltonBuchanan, 1822) and Fali chanda (Pampus argenteus, Euphrasen, 1788) fish at different storage condition. M.Sc. Thesis, Department of Zoology, University of Dhaka.

10. Rabbane GM, 2006. Studies on some aspects of qualitative and quantitative changes during freezing preservation of pabda (Ompok pabda) and chapila (Gudusia chapra) fish. M.Sc. Thesis, Depatment of Fisheries, University of Dhaka.

11. Sarmin AM, 2008. Investigation on the nature and extent of freezing preservation of Mola (Amblyharyngodon mola) and Chapila (Gudusia chapra) fish while kept at $-18^{\circ} \mathrm{C}$. MS Thesis, Department of Zoology, University of Dhaka.

12. Obande RA, S Omeji and M Ityumbe, 2012. Organoleptic assessment and nutritive values of clarias gariepinus smoked using coal and firewood. Pakistan Journal of Nutrition, 11: 762-764.

13. Konosu $\mathrm{S}$ and $\mathrm{K}$ Yamaguchi, 1982. The flavor components in fish and shellfish. In "Chemistry and Biochemistry of Marine Food Products" (ed. By R.E. Martin, G.J. Flick, C.E. Hebard and D.R. Ward. AVI. Pub. Co. Inc. CT. pp. 367-404. 